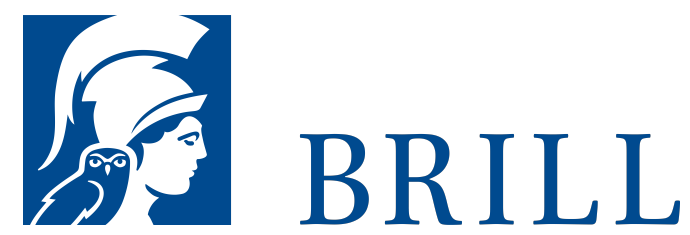

\title{
Geistliche Meditation und poetische Imagination
}

Studien zu Ignacio de Loyola und Francisco de Quevedo

Author: Christian Wehr

Mit Ignatius von Loyolas Exerzitia spiritualia aus dem Jahre 1548 verlässt die geistliche Meditation ihren angestammten sakralen Raum. Von nun an findet sie Eingang in die unterschiedlichsten Bereiche des kulturellen Lebens. Welch machtvollen Ausdruck sie in der Literatur des spanischen siglo de oro gewinnt, kann vor allem das lyrische Werk des grossen Barockdichters Francisco de Quevedo bezeugen. Die Exerzitia spiritualia stehen für eine innovative Überbietung der mittelalterlichen Meditation. Da der Jesuitenorden auf den geschlossenen Raum des Klosters verzichtet, werden die Geistlichen Übungen örtlich unabhängig und schon in der frühen Neuzeit nahezu allgegenwärtig. Ihre Spuren finden sich in den populären Alltagskulturen ebenso wie in den Verhaltenslehren der höfischen Eliten. Besonders nachhaltigen Einfluss sollte das jesuitische Meditationsprogramm jedoch auf eine barocke Ästhetik der Suggestion und Stimulation gewinnen.

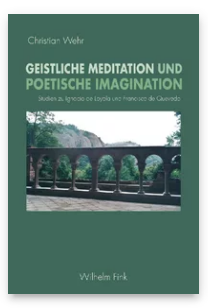

Pages: 283

Seiten

Language:

German

Subjects:

French \&

Francophone,

Literature and

Cultural Studies

Publisher: Brill |

Fink

E-Book (PDF)

Released online:

o3 Feb 2020

ISBN: 978-3-

8467-4306-5

List price

USD $\$ 63.00$

Paperback

Publication date:

18 Mar 2009

ISBN: 978-3-

7705-4306-9

List price

USD \$63.0o 
For more information see brill.com

Order information: Order online at brill.com +44330 333 0049 | customerservices@brill.com Submission information: brill.com/authors

Titles published by Brill | Fink, Brill | mentis or Brill | Schöningh: +49(o)715413279216| brill@brocom.de 